
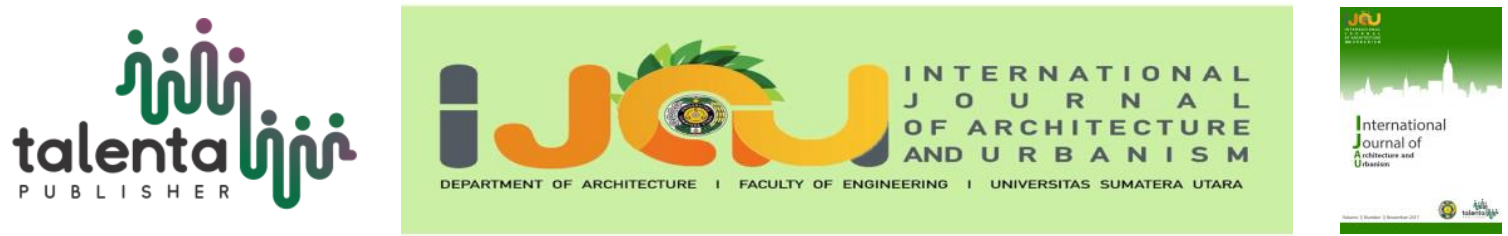

\title{
The Design of Fishing Village Tourism Banjar Belawan
}

\author{
Dwira Nirfalini Aulia ${ }^{*}$, Muthia Faradiba ${ }^{1}$ \\ ${ }^{1}$ Department of Architecture, Universitas Sumatera Utara, Medan, Indonesia
}

\begin{abstract}
The design of Kampung Wisata is intended to improve the living standards and environmental quality of the Kampung Nelayan area. As we know that, the location is the formation of slum areas whose land ownership is still illegal and the majority of the population work as low-income fishermen. These conditions cause the environment look too grubby with scattered rubbish and the lack of environmental utilities. Though in addition, Kampung Nelayan region, particularly Kampung Banjar has a variety of potential that can be used as a capital to developed into the tourist attraction. This also can be used as a place to develop slum areas become a better place which can compete in the future.
\end{abstract}

Keyword: settlement, slums, village tours, tourist attraction

\section{Introduction}

Tourism is one of the most general options which popularly developed by the local governments of a city. Currently, many rural and coastal areas become a tourist attraction that mostly visited by tourists. In the city of Medan itself, a settlement of the coastal area located in Belawan region known as Kampung Nelayan. Fishermen's village is still classified as slum settlements due to lack of awareness of the local community. Also, the lack of facilities and infrastructure facilities also became one of the factors of trigger slum. However, behind the environmental conditions that are bad, Kampung Nelayan has the potential to be made as a Tourism Village. In this case, we can review the terms of natural environment and social environment and also the culture of Kampung Nelayan community. This way is a very supportive thing for the development of Tourism Village where there will be processing and potential utilization.

\section{Literature Review}

The population is a society that occupies on this area and has a significant role in the progress. In a Tourism Village, it is very important to aware towards tourism. The awareness means that people should understand the essence of the world of tourism and enjoy the results [1].

*Corresponding author at: Department of Architecture, Faculty of Engineering, Universitas Sumatera Utara,

Jalan Perpustakaan Gedung J07, Medan 20155, Indonesia

E-mail address: dwira_aulia@yahoo.com 
According to A.J., Norwal tourists are every person who travels from his residence to visit elsewhere by enjoying the trip and visit. To meet the needs of space residents and tourists will be designed a settlement consisting of residential and homestay. Based on Law No.40 Year 1921 about housing and settlement is a building that functions as a residence or occupancy and family building facilities. Most of the people living in coastal areas are in slum categorical conditions. This case is also supported by the low level of the economy. In this code, should be able to review the occupancy of a simple house healthy. The healthy house is a house built by using building materials and simple construction but still meet the standards.

Tourism Village is a rural area that offers a whole atmosphere that reflects the authenticity of the countryside both from socio-economic life, social culture, customs, daily life, has a distinctive architecture and village structure, or unique economic activities for the development of various components of touris [2]. The criteria of a tourist village can be tourist attractions, distance, size, the system of community confidence, the availability of infrastructure and public facilities and transportation services.

\section{Methodology}

In the process of designing this Tourism Village, design method used is a descriptive method, that is by describing the data obtained both in the form of primary and secondary data. Primary data is directly from the survey results both in information and images on the Fishing Village, especially on Banjar Village. While a secondary data is from literature study. After that, the data will be analyzed that will be design concept.

\section{Result and Discussion}

Location of the site is in Fishing Village and located on the coast of Belawan City. Based on the division of the region in Fishing Village, this area is divided into three namely Clam Village, Middle Village, and Banjar Village. Size The site location for this design is $20000 \mathrm{~m}^{2}$ or 2 ha. The only means of transportation used to reach the location is Banjar Village in Fishing Village is a fishing boat. This boat can accommodate 5-8 people payload. Existing environmental conditions surrounding the site still looks very natural cause located at the mouth of the river and sea. Furthermore, there are areas of debt mangrove around that (Figure 1).

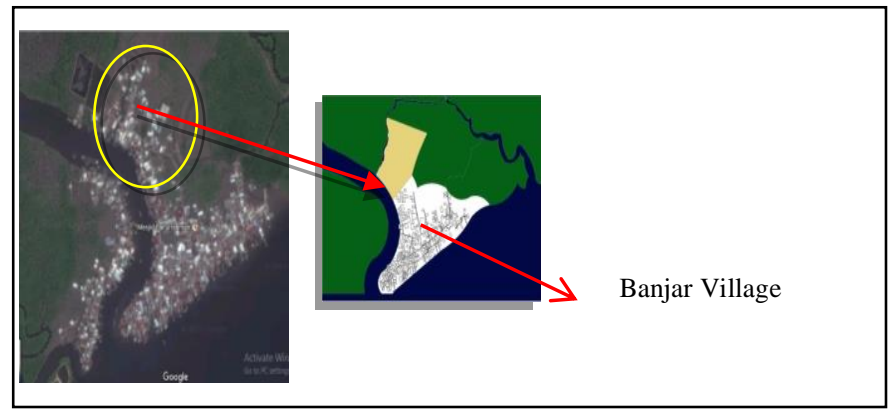

Figure 1. Site Location 
The people who occupy the village of Banjar Nelayan majority have residence status as the community of Paluh Kurau Village. The total population in 2017 consists of 45 heads of households (KK) while in 2005 the population reached 50 families. Based on the calculation of the rate of population growth, the designer can calculate the occupancy needs to be targeted for the future based. So the rate of population growth Banjar Village in the years 2005-2017 is 0.002. Based on the calculation of population growth, the population in the year 2030 is 193 inhabitant who is divided according to Head of Family. So it can be concluded that the number of residential homes that are needed to move Banjar Village residents if one head of the family inhabited by four souls is \pm 50 housing units. The main activities of Banjar Village community based on community profession are (Figure 2).

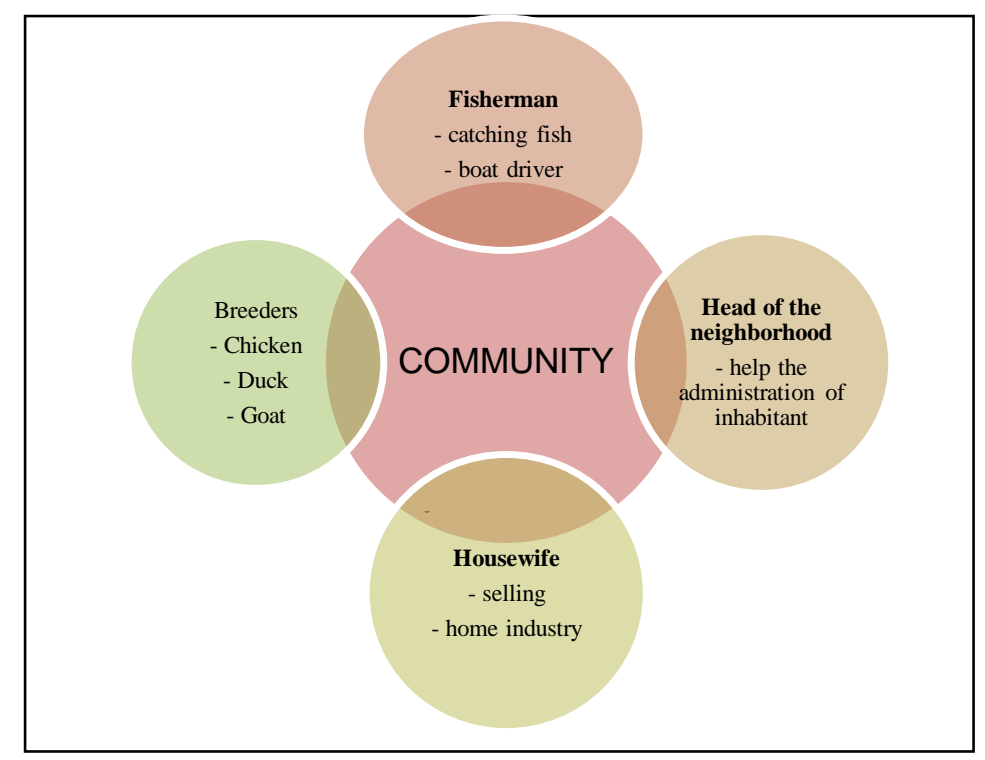

Figure 2. The Main Activity of Kampung Banjar Community

The needs of space for the inhabitants of the house is formed based on the number of people in one dwelling. Based on the standardization of healthy homes, the width of the house needed is \pm $50 \mathrm{~m}^{2}$. For the division of space needs in the whole area of Tourism Village will be divided based on the spatial space needs in the tourist objects listed in the graph below (Figure 3). 


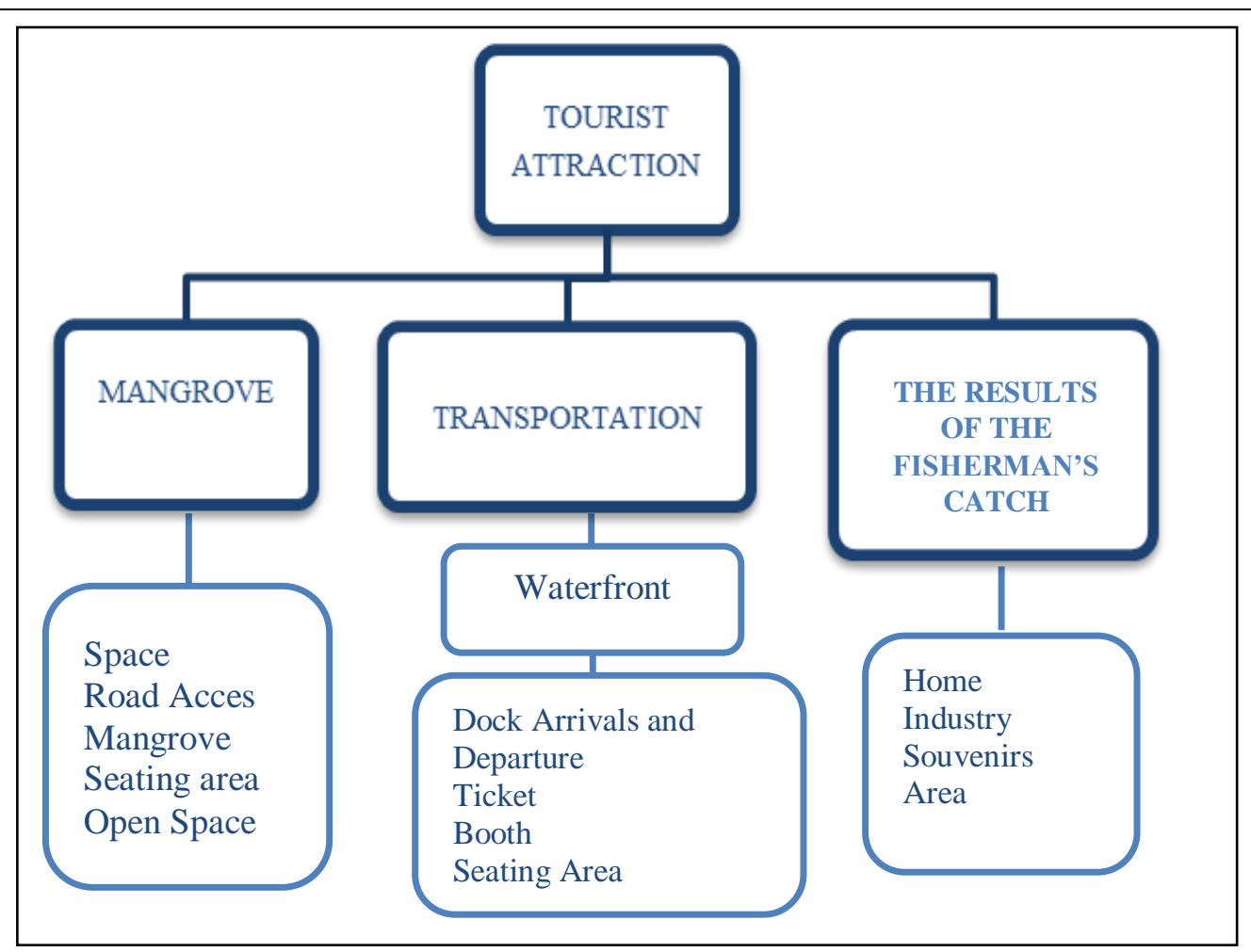

Figure 3. Requirement of Tourist Attraction

Banjar Village area located in the estuary of the river and sea that make buildings and roads in the area using stage structure with wooden construction. As for the utility area supporting facilities such as electricity is met, only for clean water and drainage facilities are still Minimally found in the area of Banjar Village. The design of Tourism Village takes the concept of land conservation where the initial tread conditions will be maintained only will be added and repaired to buildings or facilities that are damaged or unfavorable. The figure below shows the transformation of the old to the new area (Figure 4).

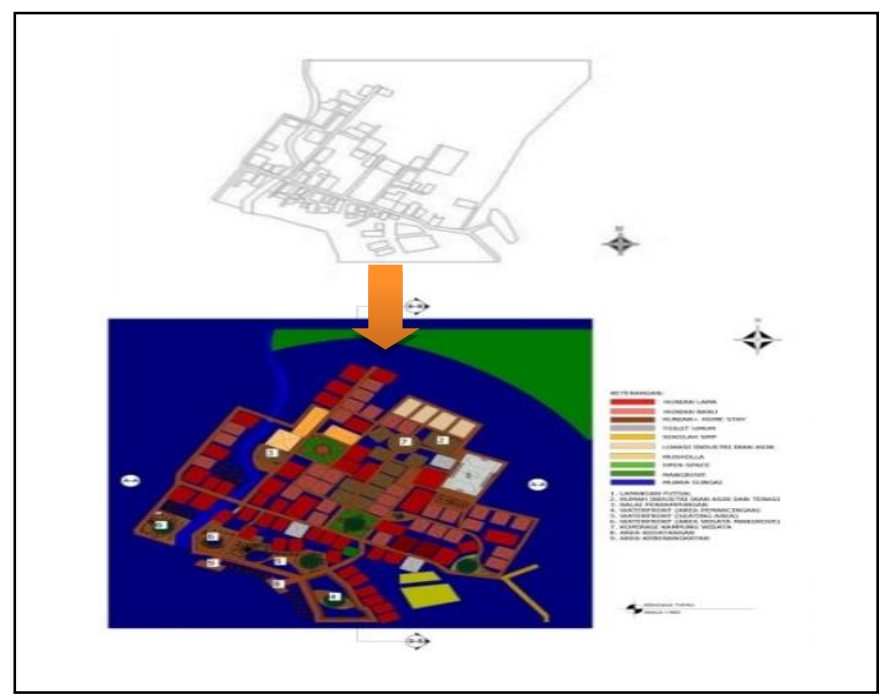

Figure 4. The Concept of Zoning Area 
The concept of activities throughout the Tourism Village area will be managed by an institution known as POKDARWIS* that is a conscious tourism group. This institute will regulate the overall process of processing tourist destinations, human resources (HR), care village tour to the distribution of proceeds from the village tour. The processing procedure results by POKDARWIS agency described can be seen in Figure 5. Also, as for the concept of tourist destinations in the village tour offered can be seen in Figure 6.

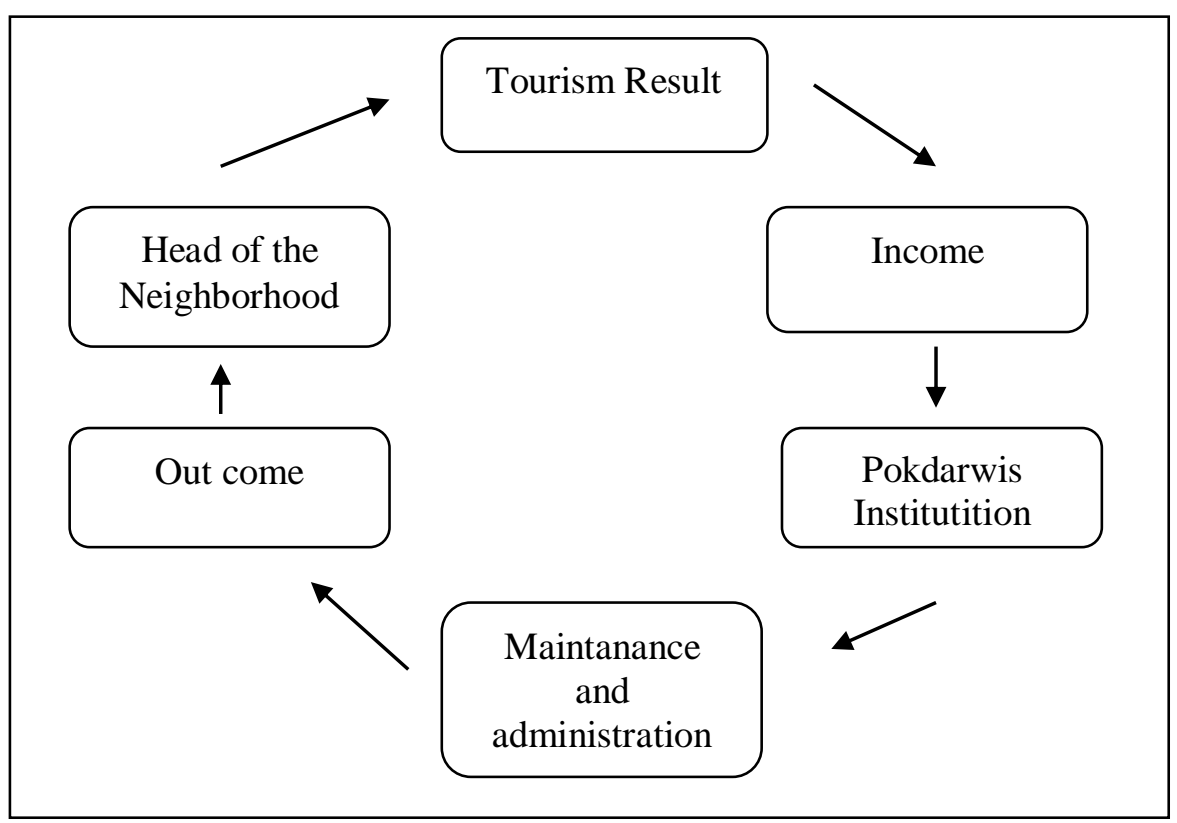

Figure 5. The Concept of Processing Tourist Results

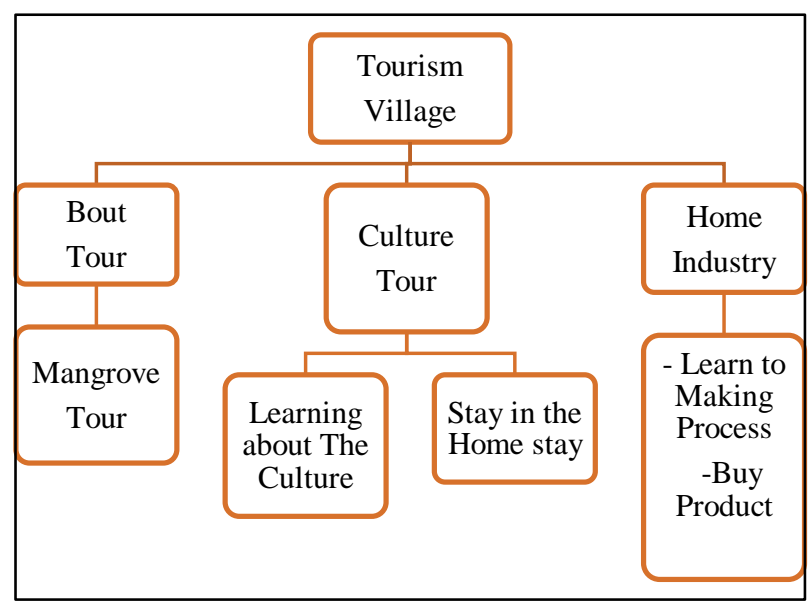

Figure 6. The Concept of Tour Destination

\footnotetext{
${ }^{*}$ POKDARWIS (Kelompok Sadar Wisata) adalah sebuah lembaga di tingkat masyarakat yang anggotanya terdiri dari para pelaku kepariwisataan yang memiliki rasa tanggung jawab dan peran dalam meningkatkan pembangunan daerah melalui kepariwisataan dan memanfaatkannya bagi kesejahtraan masyarakat.

POKDARWIS (Tourism Concious Group) is an institution at the community level whose members consist of tourism actors who have a sense of responsibility and role in promoting regional development through tourism and utilizing it for the welfare of the community.
} 
The settlement pattern of the population takes a linear form. Settlements will be arranged along and oriented towards the road. This condition is shown in Fig.7. For the spatial dwelling will be divided into several areas. In Figure 8 it is seen that the occupancy is divided into two types, namely homestay dwelling and residential stay. The rest of the old occupancy will still be maintained the existing culture of the region (Figure 7 and Figure 8).

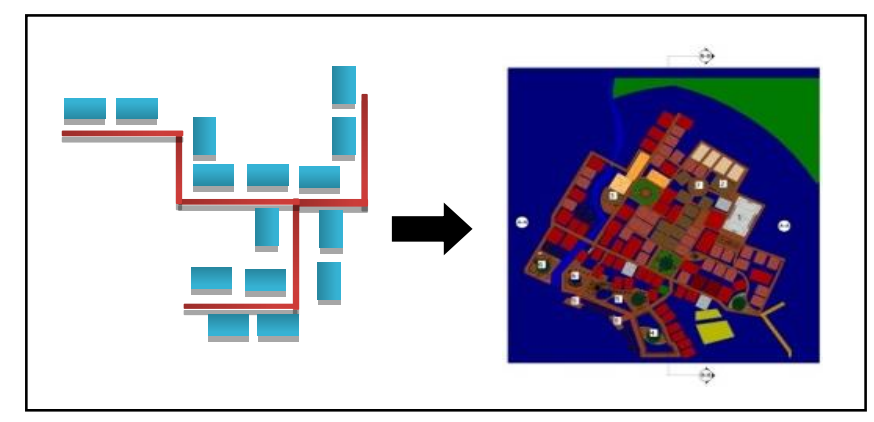

Figure 7. Settlement Patterns on The Site

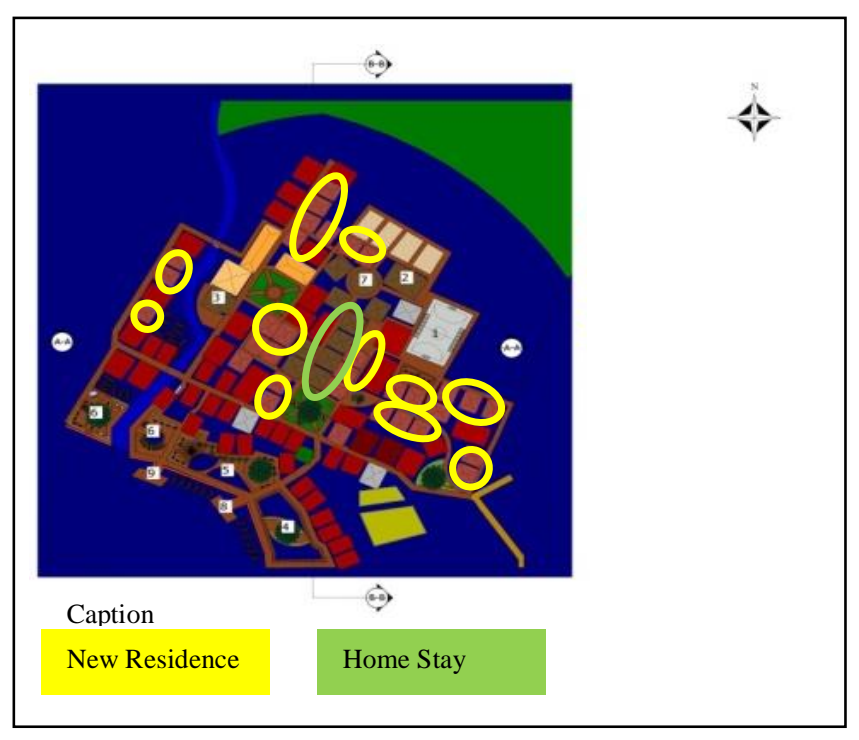

Figure 8. Spatial Layout

The concept of the tourist attraction will be classified based on existing tourist destinations. All spaces will be related to each other. Here is a graph of interconnection between tourist spaces (Figure 9). 


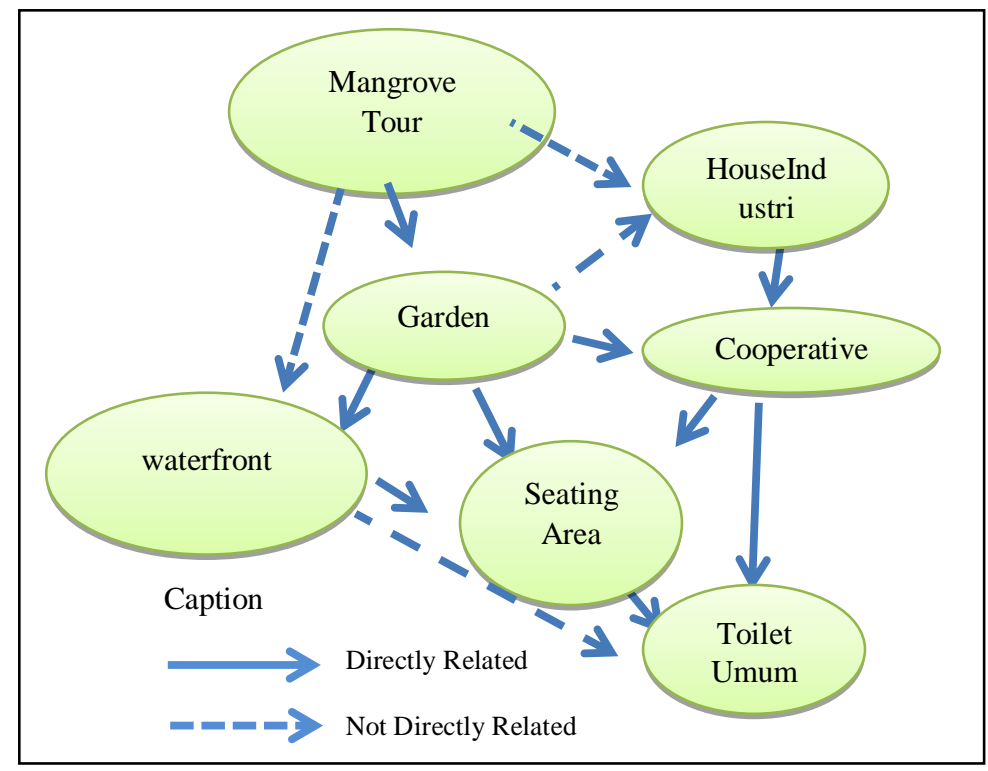

Figure 9. The Concept of Tourism Area

For the building masses in the residential area of Tourism Village very consider the use of materials, systems, and costs. This case refers to the condition of slum areas and low-income residents. Then the application to building masses using from the high to low cost. This concept will describe the use and reuse of materials derived from nature so that for the estimated cost incurred can be reached by the community (Figure 10).

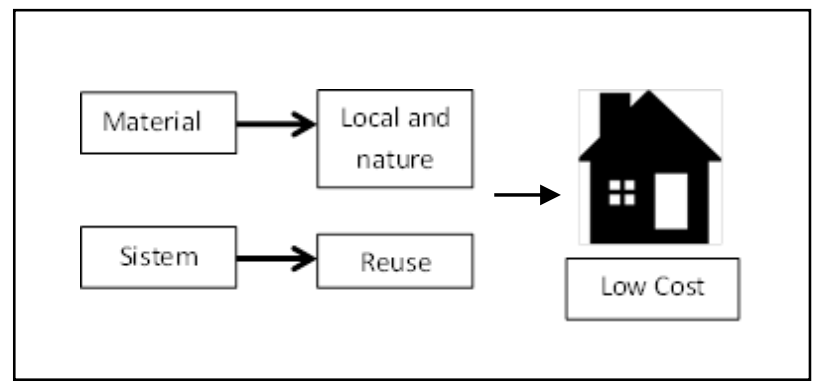

Figure 10. The Concept of Building Mass

In the design of buildings in the village of this tour will use wood construction system. This building is using a wooden frame structure. Also, the construction of this wooden building will also adopt a "panggung" building structure. It is made to respond to the condition of the land located at the mouth of the river so it must be dependent on the tidal water. To support the structure will be equipped with the foundation of bait [3]. The bases will be made of concrete lined with pipes to prevent corrosion of the concrete (Figure 11). 


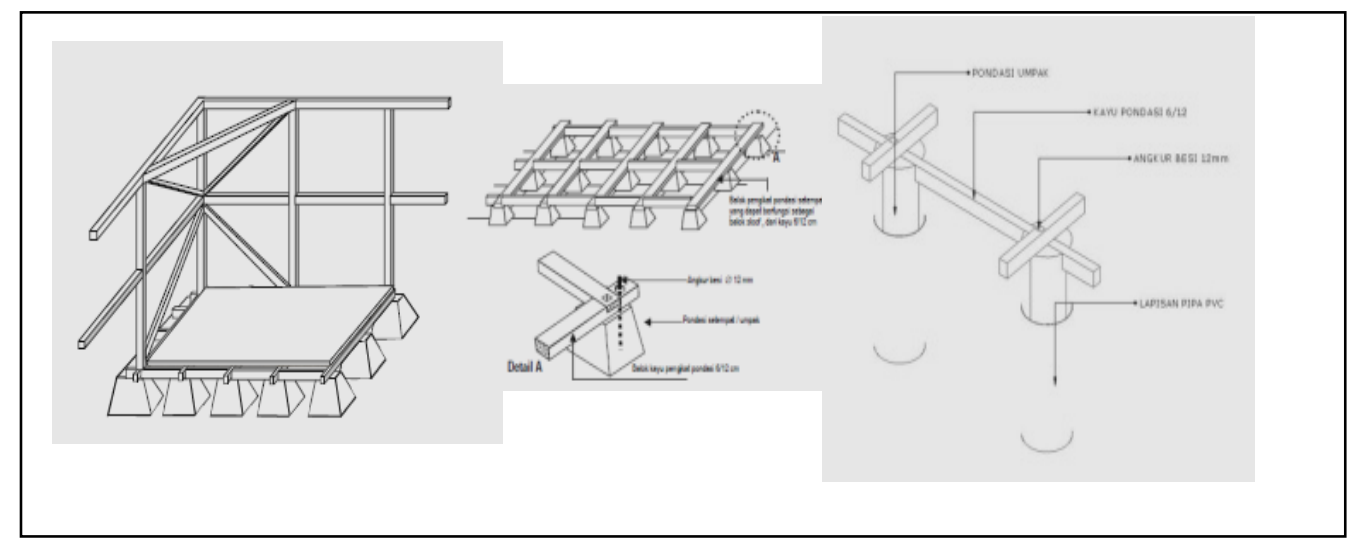

Figure 11. Building Structure

(Source: Widdjanarko: 2006)

The building utilities will be divided into three networks: clean water, drainage, and electricity. The concept is using communal divided per 10unit house to get a source and sewage treatment facilities. As for the power grid will be divided into two panels one for occupancy and the other for tourism facilities. Here is a schematic drawing layout of clean water, drainage, and electrical network (Figure 12 and Figure 13).

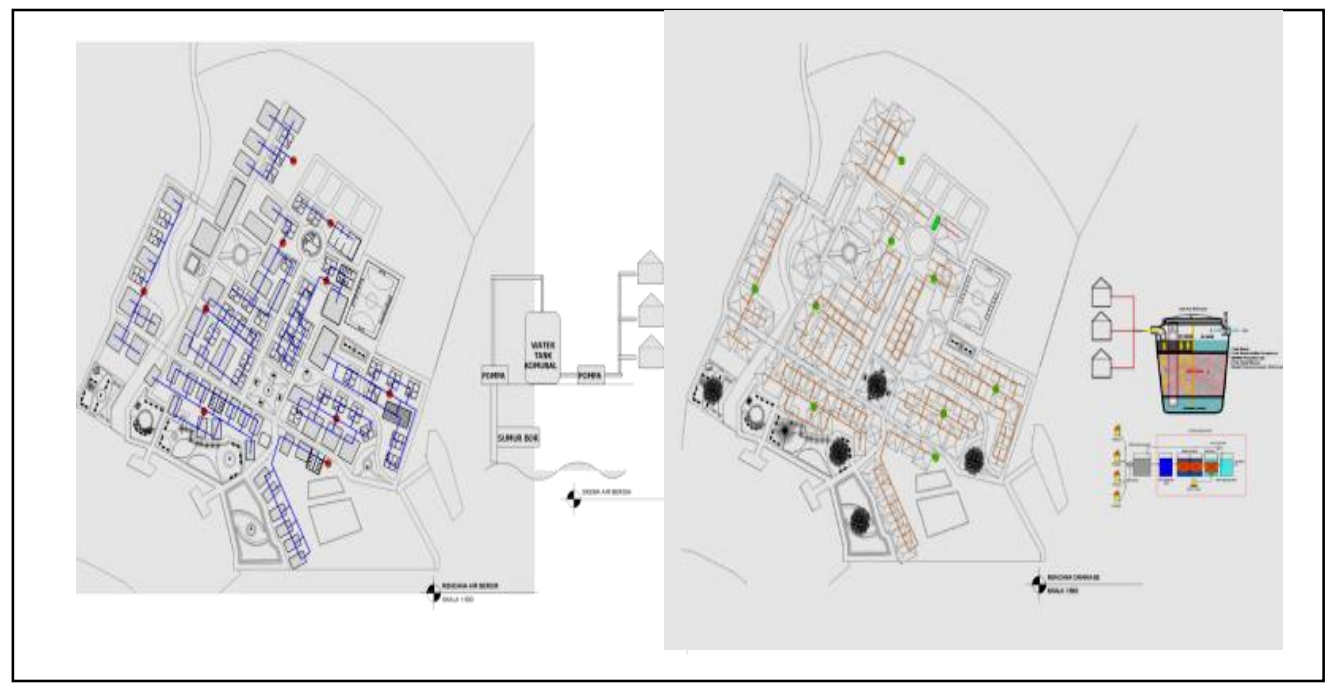

Figure 12. Clean Water and Waste Water Network

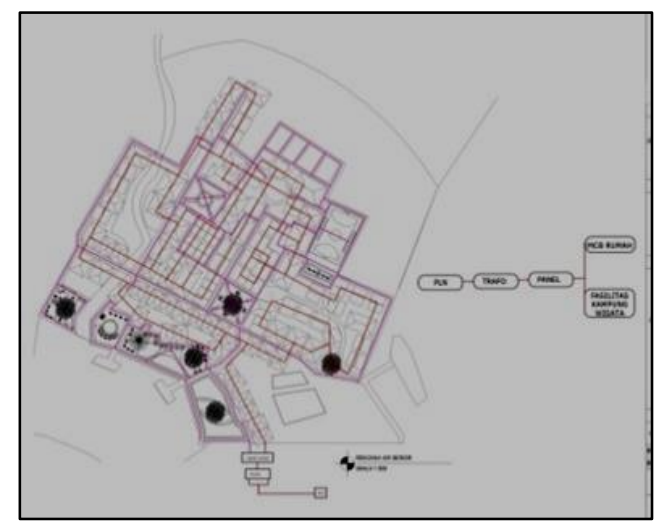

Figure 13. Electricity Network System 


\section{Conclusion}

The design of Tourism Village is based on the location of the area located at the edge of the river estuary and the potential can create a new physical environment. Not only change the area to be better even can develop a region that can give effect to the surrounding. Therefore, the concept of designing a village chosen to improve the quality of Village area is by not changing the condition of the social and cultural. To defend the existing environmental conditions, in the design of this Tourism Village will maintain some buildings that are habitable enough and the rest of the buildings that are not suitable for habitation will be repaired and redesigned with the concept of reuse and low-cost material. In addition, to supporting Tourism Village in the design will be made an institution that became the center of setting up the potential processing system in Banjar Village called the POKDARWIS. POKDARWIS itself is an abbreviation of the conscious tourism group, who will arrange all affairs in Tourism Village. For utility systems such as electricity, clean water, and drainage systems will be built that will accommodate all the needs of the community. As for waste processing will be made waste processing by the institution Pokdarwis by dividing it into two systems, namely macro and micro.

\section{Acknowledgment}

This research is part of the requirement to obtain a bachelor's degree in Architecture Department, Universitas Sumatera Utara.

\section{REFERENCES}

[1] F. Rahim. Pedoman Kelompok Sadar Wisata. Jakarta. 2012.

[2] Handayawati, Sri Hani dan Soemarno. Wisata Alam Penggerak ekonomi masyarakat. Malang: PPSUB. 2009.

[3] Direktorat Jenderal Cipta Karya. Pedoman Teknis Rumah dan Bangunan Gedung Tahan Gempa. Kementerian Pekerjaan Umum. 2006. 